\title{
Co-opting Authority and Privatizing Force in Rural Africa: Ensuring Corporate Power over Land and People
}

Gearoid Millar, PhD

Senior Lecturer in Sociology

Institute for Conflict, Transition, and Peace Research

University of Aberdeen

\begin{abstract}
:
Large-scale land investment projects in sub-Saharan African have received substantial criticism for their negative local impacts, but few studies discuss specifically their application of corporate power on the ground. This paper provides an examination of such application in rural Sierra Leone. The paper describes how one corporation both directly and indirectly coopted authority and privatized force in order to wield power over the land and people. The data illustrates how local authorities and security actors were incentivized to defend the interests of the corporation as opposed to the local communities they supposedly represent and protect. Such processes ensured corporate power not only over the land, but also over the local population. The findings, therefore, demand more robust and multidimensional accountability mechanisms to avoid the corporate acquisition of power in rural Africa. Such mechanisms would demand: a) that investing corporations be more informed about local socio-cultural, economic and political dynamics on the ground, b) that funders and local governments fund, report on and enforce more regular, culturally sensitive, and independent assessments of project impacts, and c) that funders, governments, corporations, and customary elites be held accountable for the negative impacts of such projects by international and national civil society organizations.
\end{abstract}

\section{Keywords:}

Development; Africa; Political Sociology and Political Economy 


\section{Introduction}

Much attention has recently focused on the contemporary global "land rush”. This term refers to the substantial increase in land leases and purchases in the Global South by corporations and states of the Global North, either for speculation or for the purpose of producing food, fuel and feed (Millar 2016a). The case examined here is an example of the latter, in that it sought to produce ethanol in rural Sierra Leone for export to Europe. This project also claimed to be a positive social actor within this impoverished post-conflict context by engaging with local communities to employ local labour while protecting local livelihoods and food security. However, the implementation of this project also involved the application of power via the direct and indirect co-optation of authority and privatization of force in defense of the corporation's interests and to the detriment of local non-elite communities.

Many have associated the contemporary Land Rush with the long-term degradation of the state to the benefit of corporate power (see McMichael 2013; Cotula 2013; Wolford et al. 2013). Ince noted that the "coercive taxes, debt-induced dispossession, and various schemes of land reform pushed through by colonial and postcolonial sovereign states have structured the enduring conditions" of the contemporary phenomenon (2014:125), while Franco et al. argue that broader processes have served to "consolidate neoliberalism internationally by strengthening markets while shrinking states” (2013:1659). The result is the "expansion of opaque transitional networks that control the land" (Sassen 2013:27). Land rush projects are seen, in short, to be rooted within an international system saturated with corporate power. But in what manner and to what extent do such projects deploy power over land and, just as importantly, over people? And in what ways and to what extent might local actors respond to that deployment? These are the questions addressed in this paper. 
'Power' is not itself a particularly well understood concept and it is too often deployed without definition or put on the same level of generality with concepts such as authority and force. But as this paper will show, a more subtle Weberian understanding of power as "a general category that subsumes authority, force, and other means of power" (Uphoff 1989:298) allows for a closer examination of how corporations interact with and influence local socio-economic and political dynamics and how power is mediated, or potentially might be responded to, by specific local actors. Through this lens, therefore, the paper illustrates how corporations both directly and indirectly co-opt authority and privatize force as twin bases of their power over land and people. At the same time, this analysis also reveals how those processes can play into the hands of the local elite actors who mediate between the corporation and the local communities.

As such, this paper provides an examination of the interplay of power between different actors: the corporation, the local elites (both formal and customary), and the local non-elites (residents of effected villages). By presenting primarily observational data describing such interactions, collected at community meetings where the actors interacted and communicated, the paper contributes to our understanding of how power operates within rural societies. The data supports Uphoff's argument regarding the disaggregated nature of power, while describing also the mediating role played by local elite actors in situations characterized by competing logics of authority. In such settings, as the data will describe, local elites exert their own agency by aligning themselves with the company for their own self-interest, and acting to further marginalize those already excluded from influence.

The paper is divided into five parts. Part one discusses the importance of power over land and people within the contemporary land rush and introduces the pertinent theories regarding power, authority and force which will be central to later analysis. Part two describes the land-deal itself and the context of post-conflict Sierra Leone, and part three 
explains the methodology used to examine the impacts of this land rush project over 7 months of fieldwork in 2012-2013. Part four presents the data, focusing on describing how the company co-opts authority and privatizes force within the local setting. Part five reflects on this deployment of force and authority, on the complex relationship between these two bases of power, and on the benefits of examining these bases as opposed to a disaggregated concept of power. The final section summarizes the paper and provides recommendations for more robust and multidimensional accountability mechanisms in such cases.

\section{Theorizing Power in the Global Land Rush}

Although many reports between about 2008 and 2011 describing negative impacts from land rush projects proved to be somewhat simplistic (Edelman et al. 2013:1519; Millar 2016a: 208), more nuanced scholarly publications have maintained a generally critical stance. These studies have since described such projects as instances of “water grabbing” (Woodhouse and Ganho 2011; Mehta et al. 2012), “green grabbing” (Fairhead et al. 2012), biofuels expansion (Mol 2007; Borras et al. 2010; Holleman 2012), the commodification or financialization of land (Verma 2014; Makki 2014: Gunnoe 2014), and corporate accumulation (White et al. 2012; Geisler and Makki 2014). Others have described the negative implications of such projects for governance (Margulis et al. 2013; Wolford et al. 2013), for food security (Sage 2013; McMichael 2014), for gender relations (Doss et al. 2014; Millar 2015a), and for peace and social stability (Millar 2016b).

Further, while the structures and impacts of such projects, including the one studied here (Millar 2014, 2015a,b, 2016a,b,c), are quite variable (Borras et al. 2013:1724; Tsikata and Yaro 2014:203-204), troubling patterns seem nonetheless evident. It has become clear, for example, that speculation over future land values is inspiring many of the reported land acquisitions (De Schutter 2011:253; McMichael 2013:49; Franco et al. 2013:1654; Fairbairn 
2013:342; Ossome 2014:159), that much of this activity results in deals on paper that never reach the implementation stage on the ground (Edelman et al. 2013:1525; Buckley 2013:432), and that local actors and national governments are often involved in what were initially framed as “land-grabs” by external actors (Baglioni and Gibbon 2013:1562; Margulis et al. 2013:11; Cotula 2013:1611).

More foundational than many of these specific concerns, however, are broader fears about ongoing reconfigurations of the relationship between capital, land, and production. Margulis et al., for example, note that the pace and scale of the current phenomenon, nested within the context of "globalization”, "late capitalism” and “multiple food-energy-climatefinance crises”, mark it as “distinct from previous eras” such as those during early capitalism in Europe and colonialism in the Global South (2013:2-3). It is for similar reasons that Verma argues that the individual cases of land-grabbing are symptoms of “a perfect storm of financial, climate, energy, food, and development crises coming together” and, as a result "new forces, intensities, and the hyper speed of dispossessions are shaping the way land is grabbed” (2014:65). The shared characteristics between these land rush cases, therefore, give rise to broader concerns about underlying shifts in the relationship of transnational capital and corporate power to land and local communities.

Whereas land was previously “socially embedded” and therefore key to local or national identity and meaning making, today it has been commoditized (Cotula 2013:1605) and, even if technically still inalienable as is the case in rural Sierra Leone (Fanthorpe 2001:379), is available on the market for long-term lease. As a result, African land in general is less and less considered central to community identity or even state sovereignty, but as a resource to be titled, purchased, and exchanged (Platteau 1996). This reflects, as Franco et al. describe, "the ideological ascendancy of neoliberal corporate power across domains" (2013:1661). As such, land is being made ever more open to control by powerful agents in 
the form of Foreign Direct Investment (FDI), whether via purchase or lease, and "is essentially organized to accommodate powerful private interests” (McMichael 2013:56).

There is little question, therefore, that a great amount of land is now subject to corporate power and control - the ability to "determine how the land will be used" (Doss et al. 2014:9) - even when it has not actually changed ownership. Margulis et al. go so far as to argue that the current land-rush is not about owning, accessing, or utilizing land at all, but simply about “control grabbing” (2013:13). They argue that the current phenomenon is primarily an effort to ensure future control over land as it is "an important site of new transnational struggles for authority and control over resources and governance” (ibid:3). In this sense the contemporary land rush is primarily an attempt to bring under corporate control, even if not under corporate ownership, land which global capital has thus far failed to make productive and which is therefore seen as “unused," “empty,” “marginal,” "public,” “underutilized” or “frontier” (see De Schutter 2011:258; McMichael 2013:53; Scoones et al. 2013:473; Oliveira 2013:264; Dwyer 2013:318; Baka 2013:410; Verma 2014:66).

But, tellingly, land is not the only resource that must be controlled. In order to benefit from the power to control resources you must also have the ability to access capital and labor (Ribot and Peluso 2003). Those who have this ability can benefit disproportionately from the control of the commodity. This highlights that it is important not only to examine who has power over land, but to understand also who has power over people. These are central issues that often seem tangential to a literature that focuses on the issue of "land" grabbing and "land" control, as it means that within these new configurations of global capital investors need also to have power over individuals and communities. We must see land rush projects, therefore, as concerned as much with power over people as they are with power over land. As such, they are inherently about authority and force. 
However, it is important before proceeding to distinguish between these three central concepts - power, authority, and force - and to provide a framework for the analysis of how power is applied in land rush cases. Norman Uphoff's analysis of Weber's theory of power provides some insight. As Uphoff notes, “power is often treated as synonymous with authority” (1989:296), but Weber was explicit in distinguishing authority and force as "bases or means of power” and not synonymous with power itself (ibid:299). To Weber, authority and force are both separately - but also when in cooperation - avenues to power. With regard to specific definitions, Uphoff argued that authority relies for its “existence” on "some special position or role which enables a person in it to make commands in the name of the group and to back them with rewards or sanctions in its name” (ibid:301). As such, authority is rooted in an office, a station, or a position recognized by those who must confer legitimacy (ibid:301).

In Sierra Leone, as is true for much of post-colonial Africa, there are two different categories of such authorities; the civil and the customary. Following Mamdani (1996), many recognize today that these systems were co-constituted in colonial and post-colonial Africa as separate systems. It was during colonialism that most African societies became bifurcated between the urban society, governed by civil or formal law in which individuals are seen as citizens, and the protectorate society, subject to traditional or customary rule in which individuals are subjects (1996). In such bifurcated societies, authority has two potential legitimating logics and so there are, equally, two potential paths to power via authority; the formal and the customary. As highlighted by Ribot, however, the bifurcated nature of such societies also leads to difficult interactions when actors attempt to bridge this divide, such as when plural systems undergo processes of decentralization intended to extend democracy and by extension the reach of the formal - into areas dominated by customary authorities (Ribot 1999; Ribot, Chhatre and Lankina 2008). 
Such observations indicate the difficulties - but also opportunities - that arise for corporations attempting to navigate competing logics of authority in rural Sierra Leone. Any such actor must recognise that there are various authorities operating not only at different levels but via competing logics. In Sierra Leone this is further complicated as both the formal and customary authorities have deteriorated in recent times; the state collapsed in the late 1980s and still has limited capacity in rural areas, while customary authorities lack the resources necessary to incorporate the enormous numbers of unoccupied youth. As Fanthorpe has described, Sierra Leone may "represent a case in which alarming numbers of people have become neither 'citizen' nor ‘subject'”; where neither formal nor customary forms of authority hold sway (2001:385).

In such a context, where logics of authority are contested and so cannot serve as clear bases for power, land-rush projects cannot rely purely on the co-opting of authority as the base of corporate power, and may turn, as the data will show, to the use of force. Force, as discussed here, is a parallel base of power defined as "the physical capacity to compel or injure others” (Uphoff 1989:319). Force is understood to have a limited capacity as a means to power as it cannot be used freely without eventually undermining other bases of power, such as economic resources, legitimacy, authority or the moral high-ground (ibid). However, in the form of threat, force can maintain a much longer use. Threat can be "understood as the 'currency' for force, having the same relationship to it as money has to goods and services as a unit of measurement, a medium of exchange, a store of value, and/or a standard of deferred payment” (ibid:314). Seeing threat as the currency of force allows us to see force as operational and applied as a potential, even if not applied physically.

As Boulding articulated more than 50 years ago, "threat in its simplest form is a relationship between two parties” which originates in a promise by the threatener to do something bad to the threatened if their demands are not met (1963:426). But threats - like 
currency - must be representative of an underlying value, of a real potential of compulsion or injury. In this sense, the value of a threat is based on the credibility of its being carried out, and the willingness of the threatener to follow through (ibid:428). Threats that are made and not carried out reduce the value of future threats and so devalue the control of force. As such, force is a base of power via threat for only as long as the economic resources, legitimacy, authority and moral high-ground necessary to support its use are maintained, and for only as long as the threat remains compelling to the threatened. What follows is an analysis of the ways in which the corporation involved in the land-grab project attempted to co-opt authority and privatize force (often via threats) in rural Sierra Leone and how this process was mediated by and responded to by local actors.

\section{The Context of this Study}

As a fragile post-conflict context rural Sierra Leone is of particular interest as the site of a large land rush project (Peters and Richards 1998; Fanthorpe 2001; Millar 2016b). The war in Sierra Leone is often described as characterized by arbitrary violence, the weakness of the state - which failed to enforce order over a period spanning more than a decade (1991-2002) - and the frequent targeting of non-combatants resulting in the regular abuse of civilians in the form of child soldiering, amputations, sexual violation, death, and displacement (see Shepler 2005; Park 2006; Bolten 2012). But many also identify its root causes in the scale of impoverishment prior to the war (Pham 2007), the large number of unemployed and unoccupied youth (Abdullah 1998), the failure of the patrimonial system of governance (Kpundeh 2004), and the presence of alluvial diamonds (Hirsch 2001). Indeed, various scholars have noted the toxic combination of these characteristics and the particularly dire economic situation in the 1980s and early 1990s for rural youth, which, it is said, inspired their participation in the violence (Peters and Richards 1998; Keen 2003). 
Sadly, however, many of these problems remain even after the war (Shaw 2010:111) and meeting basic economic needs remains the prime concern for most rural people today (Millar 2010, 2011a, 2015b, 2016b). It is in response to this need that the Koroma administration (in power since 2007) has prioritized agriculture and “export oriented agribusiness” in order to spur economic development (Menzel 2015:6). It is assumed that with such policies the private sector will play a key role in "economic growth, providing jobs, and creating wealth” (Nnadozie and Abdulmelik 2009:150) and thus countering the continuing risk of violence from disenfranchised youth. In this post-conflict contexts, however, the great worry is that in their drive to make land a profitable investment, land rush projects function to recreate or exacerbate the marginalization, inequality, and social exclusion that gave rise to conflict in the first place.

The land rush project described here was funded by a consortium of seven development banks to plant 10,000 hectares of sugar cane for the eventual processing and export of ethanol to the European market. The design of this project was widely lauded for its claims to social, economic, and environmental responsibility and indeed the project itself initially argued that it would improve standards of education, healthcare, food security, and environmental protection within the land-lease area, while also providing income to 2000 local employees, payments to land-owning families who would receive \$3.20 per acre leased, and taxes to three levels of government (local (chiefdom), regional, and national). In addition, because the project would lease 40,000 hectares of land but only plant 10,000 hectares with sugarcane, it did not require the removal or relocation of any villages, instead planting fields in and around existing settlements. However, the traditional farming lands of many villages were acquired for the construction of project infrastructure and/or planting of sugar cane and this disrupted customary land claims and well established farming patterns. 
In response to this complication the company established a farming program which provided 0.14 hectares of land for every resident of each village, assisted in planting, cultivating, and harvesting rice on that land for the first three years of the project, and taught local farmers more efficient farming practices. It was hoped that each village would be able to continue to farm on its newly allotted plots with new techniques and to re-establish its own food security within the land-lease area of the project after the first three years. Although the local experiences of these remedial processes were quite mixed (see Millar 2014, 2015a,b, 2016a,b,c), the company was attempting to administer remedial practices which it claimed would counter the disruptive or negative impacts of its processes; i.e. the construction of roads, pipelines, pivots, and a large ethanol processing factory, and all of the social, economic and political impacts accompanying such efforts.

\section{Research Methodology}

With few exceptions (see White and White 2012; Grandia 2013; Bond 2014; Millar 2016a,b,c) the literature discussing the impacts of the contemporary land rush have been theoretical, anecdotal, or have relied on analyses of national or international level data. As Scoones noted “[f]ew assess whether anything is happening on the ground” (2013:473; see also Oya 2013:511; Edelman 2013:490). This article, therefore, builds on previous publications regarding the reconfigurations of land-control in local settings, but using more grounded ethnographic data collected over 7 months of fieldwork in 2012 and 2013 exploring the local social and economic impacts of one large bio-energy project.

Over these 7 months I first spent six weeks conducting participant observation within the company, focusing on its processes and practices, but particularly on its interactions with local individuals and communities. Following this I spent extensive time in 12 villages within the land-lease area, conducting 55 semi-structured interviews in 2012 and a further 60 upon 
my return in 2013 with individual residents of those villages. Ten of these villages were sampled randomly - 2 from each of 5 phased development areas - and two additional villages were selected based on their proximity to large elements of the project's infrastructure. In each village I purposefully spoke to a diverse range of men and women, as well as the young and the old, and from land-owning and non-landowning families. On returning in 2013 I was able to interview at least one original interviewee in each of the 12 villages and to examine in detail how the process developed and changed over time.

In these interviews I wanted participants to describe what they knew and how they felt about the company and its project, and what they or their family and friends had experienced of the project's processes. In each interview I first asked what the interviewee could tell me about the project, and I then asked follow-up questions to explore central issues for the research which I had outlined previously. These issues included employment opportunities, salaries, treatment of employees, social, gender and generational inequalities, impacts on farming and social relations, and food security. I was also open to exploring other issues the participants themselves brought up. Both the observations and interviews were analysed using qualitative analysis software (Atlas.ti), and all research 'subjects', here including both the company and anyone interviewed during the research, are accorded full anonymity.

It is important to address the potential impact of my own position as a white male European conducting research regarding potentially sensitive issues in an impoverished area of rural Sierra Leone, which raises questions regarding status, privilege, communication and data reliability. It is for such reasons that I worked with a trusted translator and research assistant who I have known since starting my research in northern Sierra Leone in 2008 and who is fluent in English, Temne (the local language) and Krio (the national lingua franca) and experienced with translation and qualitative research. His experience and sensitivity to the context and to the requirements of qualitative research were constantly evident in his active 
participation in informal conversations with village residents, astute interventions with prompts and follow-up questions, and perceptive assessment of the data being collected. His nuanced interventions directly informed the development of our inquiry and my eventual analysis of the data collected, which provided great insight into the project's numerous impacts within the local social context (Millar 2014, 2015a,b, 2016a,b,c). This paper, however, is specifically focused on how the company both directly and indirectly co-opted authority and privatized force.

\section{The Bases of Corporate Power: Co-opting Authority and Privatizing Force}

One thing that is clear from the data is that the relationship between economic resources, authority and force can be quite subtle. While it may seem clear that resources and force are connected - the ability to apply force being reliant on economic resources - authority should be less directly open to manipulation by corporate actors as it is rooted not in resources but in the office or position occupied. In theory, for example, customary authorities in Sierra Leone are responsible to their clients (family, village, or chiefdom), while democratically elected representatives are responsible to their constituencies. Neither of these positions of authority (one customary and one formal) should be susceptible to the application of economic resources by corporate actors, and so the forces they administer should not be open to privatization. However, the actual situation on the ground was quite different. Both authority and force were open to manipulation in the local context, and the application of resources by the company had direct and indirect effects on both authority and force.

\section{Direct privatization of force}

I will begin with perhaps the simplest dynamic to illustrate, which is the direct privatization of force within the project area to protect the company's operations from what it saw as 
dangerous disruptions - including theft, protests, labour disruptions such as strikes and sitdowns, or outright destruction of company property. To perform this service the company employed a private security firm, which was responsible to protect much of the infrastructure of the project, such as pump stations, pivots, pipelines, offices, and compounds. Without further analysis there would seem to be nothing wrong with this; the company was a legal entity entitled to protect its interests. However, on the ground the security firm served not only to protect the company from disruptions, but - through the application of force - to control the local population.

For example, in 2012 one young woman told me of how her father had been “arrested” while walking through one of the company's fields and held overnight, only to come home the next day. The manner in which she initially told this story gave the impression that her father had been arrested for breaking a law, by police or state security forces, and held in a jail or prison. But during our conversation it became clear that he had been held by the private security guards overnight on one of their fenced compounds. The security firm had, in essence, illegally taken the man by force to their office and held him. Neither the company nor the private security contractor had the right to make arrests or to detain citizens, but the woman did not know this and in an important sense it was not the legal status of these security guards or their "arrest” of her father that mattered. Indeed, it was the impression this made on the young woman and others in her village which was important, and her interpretation was that the security guards could and would arrest local people within the land-lease area, which she saw as now under the power of the company; a power which permitted no defiance.

Indeed the security guards themselves often promoted this interpretation. On a separate occasion my research assistant and I arrived at the site where the new ethanol factory was under construction. There was a chain link fence surrounding the area and I wanted to 
get closer to the fence to take a picture of the ongoing construction. However, on approaching we were stopped by a security guard and informed that nobody could come within 50 meters of the fence. On enquiring why, I was informed that the company owned all of the land within the land-lease area and could stop anyone from entering any piece of it, whether it was behind a fence or not. When we argued that the company had only leased the land, "owned" none of it, and did not have authority to stop people from accessing land that the company was not directly utilizing, we were told that any further inquiries would have to be made to the head of security. Again, not an act likely to be taken by local village residents.

Both of these examples show how the company was not only purchasing security against illegal disruption, but also to intimidate and threaten local people and, in so doing, to undercut any resistance or opposition within the land-lease area. Few local non-elites understood the terms of the land-lease agreement, and fewer still had any understanding of their legal rights vis-á-vis the company (Millar 2014). In promoting an improper interpretation of the legal status of both the company and the residents of the land-lease area and pretending to be an authoritative agent, the security firm was miscommunicating the terms of the land-lease agreement to already confused local people and using threats of force to further intimidate them and make them feel insecure on their own land. The local community members felt dispossessed by the company and within this context the security firm was interpreted as the enforcement arm of that dispossession. But this direct privatization of force and its use for control was at least easy to identify and track. More concerning may be the manner in which the company indirectly privatized force through the local branch of the Sierra Leone Police (SLP).

\section{Indirect privatization of force}


The SLP were generally at the beck and call of the company within and around the land-lease area. There are a couple of reasons for this. First, the company was generally interpreted as having been sponsored by the government and even by the president himself and, as such, was to be protected and defended so as to show allegiance to the president. Second, as noted above, the company was a legal entity with the right to protection against infringements such as theft or destruction of property. As a result, it was the responsibility of the SLP to provide that protection. However, while every citizen of Sierra Leone was, by law, entitled to those same protections, the vast majority of local people had very little recourse to these formal structures of justice, and certainly could not so easily call on the services of the SLP to protect their interests. So we must explore further to understand why it was that the company received protections generally unavailable to citizens.

We really don’t have to look far. In interviews in 2012 and 2013 senior management on the ground were perfectly willing to describe how they filtered resources to the local branch of the SLP. They openly argued that the company must rely on the police to protect its interests and arrest anyone who might threaten those interests through illegal means. The company provided money to the SLP, not, they claimed, as a bribe or in any way to influence their practices, but so that they would be equipped to enforce the law in the region. What this meant practically was the transfer of money from the company to the local police commander, ostensibly for the maintenance of vehicles. However, within a context characterized by a constant lack of resources, salaries, and equipment - in which local people are asked to provide pens, paper, and transport money for even the most basic of police investigations this resource provision influenced who was protected and who was not. Indeed, within the locally normative patron-client system, this provision of resources located the company as the patron and the police as their client, ensuring that the SLP felt responsible to the company 
and worked to serve their needs, as is the appropriate response of a client (see Millar 2011b:187-189).

The results of this dynamic were exemplified by an event at a community meeting in 2012. Prior to this meeting, held at a village community centre and attended by the representatives of dozens of villages, there was an argument between the representatives of two land-owning families. One family argued that the other had claimed to own more land than it really did during earlier phases of the project's work; during which the company had leased strips of land for the construction of access roads. By claiming excess land, the first family argued, the second family had inflated its own share of the lease payment distributed by the company for the already completed road that ran through both families' lands. This conflict threatened to become violent as the tension rose between the men and the meeting as is true for most meetings in Sierra Leone - was increasingly postponed due to the late arrival of a number of local and district elites.

In response to the argument between the two families, which was threatening to disrupt the meeting, the company dispatched an SUV to return to the district headquarter town (about 20 minutes by car) and return with the district commander of the SLP. The district commander was then added to the agenda for the meeting and proceeded to warn all of the assembled village representatives that any conflicts between families would be reported to and settled by the police. He further expanded on this, threatening that any disruptions of the company's operations would be met with immediate police action, arrests, and prosecutions. He informed all in attendance that the company's operations should not be disrupted in any way by local communities or conflicts between families as the company had the support of the president, was providing development to rural Sierra Leone, and had the protection of the law. 
This event illustrates, in a simple but powerful way, the relationship between resources and force applied via threats. It is a clear example of the resources the company could mobilize (the SUV) to indirectly privatize the threat of force that the SLP could wield. It is particularly revealing when one considers the lack of recourse to formal legal actors that local people within the project area had; with no resources with which to mobilize police responses to their own concerns. Both of these cases, therefore, illustrate the manner in which the privatization of force undercut any substantive response or resistance from local non-elite actors.

This example also serves as a useful transition to an examination of the co-optation of authorities and the mediation of corporate power via local elite actors, as it exhibits various examples. These include the authority vested in the position of district commander of course, but also higher authorities the SLP district commander represents, such as those of the law (judges) and the state more generally (the President). This is, therefore, a clear example of where the privatization of force was closely linked to the co-optation of authority and the influence local elite actors themselves wielded as mediators of corporate power. We turn now to the direct co-optation of authority in the roles of both customary and formal elites.

\section{Direct co-optation of authority}

In addition to being an impoverished country, Sierra Leone is an extremely unequal one in which many elites have access to quality education, business opportunities, and foreign travel unimaginable to non-elites in rural areas. As described elsewhere, elites in Sierra Leone are in many ways "dissociated” from the lives of those they often claim to represent (Millar 2014:95). This is true whether we are talking about formal authorities, such as government ministers and district officers, or customary authorities such as Paramount Chiefs (the highest level of customary authority). This dissociation is particularly relevant in cases such as that 
described here, where the amount of resources being brought to bear were distributed primarily among those most likely to serve the interests of the company. Elites who could sway the opinion or actions of local people to either support or oppose company actions were, as a result, in a prime position to influence the company for their own purposes and to demand and receive substantial resources. As a result, however, while many elites managed to work themselves into beneficial positions, this also allowed the company to acquire the services of those in positions of authority; co-opting them for the promotion of its own interests.

At the community meetings described above, for example, the Paramount Chiefs always lauded the actions of the company and warned the residents of the land-lease area against any disruption of the company’s operations. These same Chiefs control the chiefdom councils, which received 20 percent of every land-lease dollar paid by the project; or approximately $\$ 71,000$ per year collectively. In addition to this, the chiefs themselves directly benefited from payments previously negotiated with the company and supposedly given for "transport costs" for their presence at community meetings, as well as earning landlease payments as the male heads of families who control substantial pieces of land. To make clear the level of dissociation and the unequal manner in which the resources of the company are distributed, each of the three Paramount Chiefs involved in this project made more in transport costs for coming to a single four hour community meeting (which company staff informed me was about \$90) than labourers working for the project were earning per month (between $\$ 70$ and \$85).

In addition to these customary authorities, formal authorities were similarly directly co-opted. A Member of Parliament for the area, and the person regularly identified by village residents as the most active proponent of the project, represented the area where the company initiated its work in 2009. His constituents regularly cited him as the reason they initially 
supported the company. Some said that he had convinced them of the value of accepting the company, others that he had repeatedly pressured them into accepting the company, and still others that he had actively promised many good things that had then not materialized. However, when effort was made to contact him for an interview it was discovered that he was travelling in Switzerland, at the invitation of the company. This must be interpreted as another example of an authority being directly co-opted by the company, purchased this time via travel opportunities and gifts. This Member of Parliament, formally responsible for representing the interests of his constituents, had positioned himself to gain personally from the project while promoting it to his constituents.

\section{Indirect co-optation of authority}

While direct co-optation of authority is easy to identify, indirect co-optation is more subtle. Two examples are provided. The first is the indirect co-optation of customary authorities through the regular reference to the company's respect for tradition, for ceremony, and for the community elders. At the beginning of every meeting the attending Paramount Chief (or his representative) would thank the company for including them, and for respecting the tradition of Chiefly rule. They would reiterate that the company had come to the Chiefs first and negotiated the land-lease with them, and this, they would reiterate, was a sign of respect for local tradition and for Sierra Leonean culture. In regularly repeating this the Chiefs were distinguishing the this particular bio-energy company from prior interventions (from mining companies, from civil-society organizations, and even from the government) which they saw as intruding on their Chiefly authority and so as disrespecting local traditions. But in repeating this regularly to the local people, the Chiefs were also rhetorically and performatively imbuing the company with traditional legitimacy. 
A similarly indirect co-optation of authority can be witnessed in the role played in this project by President Ernest Bai Koromo. This dynamic is particularly interesting because the President really played a very minimal role. There is no evidence that he was actively promoting the company or speaking publicly about the project. But given this lack of a direct role, it was remarkable how often his name and title were deployed to promote the interests of the company. This first became clear in the voices of villages residents, who made constant reference to the President as the authority behind the company. He was referenced with an air of respect and humility among those in the villages and identified as the person they believed had invited and supported the company to start their work in Sierra Leone. He was often mentioned when they explained why they themselves could not do anything to resist the company or its operations. It had been brought by "Pa Koroma," they said, so who were local people to doubt its value.

But to what extent can we say that such references to the President were a co-optation of this authority? Can it be said that the company was actively and consciously appropriating the authority of his office? To answer this we must only return to the community meetings, in which the president was regularly referenced by elites such as the Paramount chiefs, the district commissioners, and other authorities. At such meetings comments from all senior men, including the Paramount Chiefs who are supposedly the most closely associated with local villages and communities, were almost always either laudatory of the company and its processes, or direct and explicit warnings against any disruption of the company's operations by the local people. Further, it was repeatedly argued that if the communities disrupted the work of the company they would be going against the wishes of the President. Over 7 months of fieldwork not a single meeting was witnessed at which the President's support for the company was not referenced at least once. These speeches served, therefore, to vest the project with the authority of the President, even though he himself was never present. 
In both of these cases we therefore see how the direct co-optation of the local elites led to the indirect co-optation of higher authorities; those of tradition and custom as well as that of the president. In many ways this dynamic echoes that seen with the SLP District Commander who also referenced authorities greater than himself; those representative of the law and the state. And, perhaps more importantly, this indirect appropriation of authority served, like the privatization of force, to undercut local non-elite actor's ability to resist or oppose the work of the project. The company did not need to directly co-opt the institutions of the law, of tradition, or of the president, as it could do so indirectly by co-opting those who could appropriate and wield that authority on the ground and counter any impetus to resistance among local non-elites. In short, the company managed - whether knowingly or unwittingly - to co-opt the most respected of local authorities (the Paramount Chiefs) as well as the highest authority of the state (the President) in order to apply power, silence dissent, and intimidate and control local populations within the land-lease area of the project.

\section{Discussion}

This paper illustrated how a large bio-energy company operating in rural Sierra Leone utilized its capital resources to both directly and indirectly co-opt authority and privatize force to control both the land and the local population within the land-lease area of the project. First, the data illustrated how force was privatized, both directly through the services of a private security firm, and indirectly through the appropriated services of the SLP. It was then shown how various positions of authority were co-opted and deployed by the company to convince doubting village residents and silence any dissent; again, sometimes directly and sometimes indirectly. Further it was shown that these two dynamics were related, with coopted authorities often deploying force in the form of threats against local people - threats 
being the "currency for force” (Uphoff 1989:314) - and thus co-opting the agency of selfinterested local-elites to pre-empt any impetus to resistance among local non-elites.

While the managers of the company were well aware of some of these processes such as the provision of funds to the SLP and the payment of transport money to the Paramount Chiefs - interview data indicates that they were less conscious of some of the more indirect appropriations of authority - such as the way the authority of the President was deployed by local elites (both customary and formal) as a means to convince or cajole the residents of villages. It is not that the company’s managers did not know that the President was being mentioned, but they did not seem to fully understand the influence or importance of his authority on the ground in the rural north of Sierra Leone and within the traditional patron-client system wherein the head-man "owns” the village and the President (Pa Koroma) is very much considered to "own the country".

Similarly, the company employees failed to fully understand the subtlety with which co-opted authorities deployed threats against the people as a means of power. In the context of rural Sierra Leone, where there is little understanding of formal law, little trust in institutions of security, and where local people have no recourse to law for their own protection, even the hint of possible arrest can be a terrifying means of intimidation. The argument made by company managers, for example, that the SLP was provided resources so as to enforce the law - with the implication that this would benefit the community generally evidences the company's willingness to manipulate and take advantage of local inequalities. But the manner in which it distributed its capital resources also incentivized the deployment of 'force as threat' by authorities (such as the Paramount Chiefs) in ways which the company may not have considered independently.

In this post-conflict context, where a decade-long war was fuelled by the economic marginalization of the non-elite rural population, the resources deployed by the company in 
many ways reproduced the dynamics that existed prior to the war (see Millar 2016b). As described in much of the land rush literature, transitions in the global circulation and influence of capital vis-á-vis the nation state system have meant the commodification of land as something to be titled and traded (Verma 2014; Makki 2014: Gunnoe 2014). But as large corporations from the global north take advantage of this opening up of "unused” land they also insert themselves, and previously unimaginable resources, into local social dynamics. The company's need to control the land, therefore, also necessitates the control of the people.

Counter intuitively, however, due to the complexity of such local contexts and the subtle interaction of authority and force as bases of power (Uphoff 1989), it is also here that the company lost full control over the outcomes of their resource deployment. As the movement of capital from the rich countries and corporations of the global north into the fragile or conflict affected states of the global south is also the movement of capital from one socio-cultural context to another, the effects, influences, or externalities of resource distribution are unpredictable and open to mediation or exploitation by local elite actors for their own self-interest. To some extent, therefore, companies lose control over their own efforts to control land and the people on it in a process reminiscent of the "Frictions" Tsing identifies in International Development (2005). The effect of such capital flows may indeed not only be unpredictable, but over a longer-term even conflict promoting.

While the company analysed here utilized its resources to co-opt authority in order to control the local people and avoid project disruption, the influence of the company's direct and indirect co-optation of authority and privatization of force on local stability and security were questionable in the longer-term as local actors sought to respond and resist. Already in 2013 (after 4 years of work) there were increasing signs of conflict between villages and families who were benefiting unequally, between the men from outside the area who were employed and those native sons the company had failed to employ, between the villages and 
the company itself, and between the youth and elders over their decision to accept the company's entry into the land-lease area (see Millar 2016b). It is a limitation of this paper that there is not space here to examine such responses at length, but these issues are further discussed in other publications resulting from this project (Millar 2015a,b; 2016a,b; 2017). However, the conflictual nature of these responses does evidence how the pre-emption of peaceful resistance via the threat of force in this still sensitive post-conflict period has left local non-elite actors with limited avenues to express their own frustrations and their own agency. This may indicate a reproduction in the post-conflict context of the status of the "lumpen” youth as “neither citizen nor subject”; essentially an issue of disempowerment which Fanthorpe argues was a key cause of the civil war itself (2001).

\section{Conclusion}

This paper has traced some of the social dynamics that arose as a large-scale land rush project attempted to control the land and people within its land-lease area in rural Sierra Leone. As such, it has both affirmed the findings of prior land-rush scholars (Margulis et al. 2013; Sassen 2013; Doss 2014; Ince 2014), and illustrated the manner in which making control of the land profitable also demands control of the people (Ribot and Peluso 2003). Further, by illustrating some of the ways in which the company utilized its overwhelming resources, the paper has confirmed the importance of a disaggregated conception of power and the relationships between authority and force as bases of power (Uphoff 1989) and of threat as the currency of force (Boulding 1963). More importantly, perhaps, the paper builds on the work of Mamdani (1996) and Fanthorpe (2001) by arguing that in bifurcated states, or contexts of contested authority, an influx of resources may serve both to co-opt local elites and inspire their deployment of threats to pre-empt any substantive response or resistance 
from local non-elite actors, ensuring control in the short-term, but potentially leaving no route for local agency other than conflict or other expressions of force in the longer-term.

It is difficult for a single case study to provide much in the way of recommendations which might challenge such problems as each case will be different and even a single case will change over time and recommendations based on dated data may no longer be pertinent. There is little reason, in short, to assume that specific recommendations for this case (also purposefully anonymized) would be pertinent to others. But what can be provided are general recommendations pertinent to the conduct of powerful corporations in rural African contexts. This case certainly illustrates, for example, the need for more robust and multidimensional accountability mechanisms to limit the corporate deployment of power in rural Africa which might, through the mediation of local elites, serve to marginalize instead of empower local non-elite actors. Any such mechanisms must serve to hold accountable the actors across numerous scales who are, at the last accounting, responsible for such projects. This includes, therefore, funders, governments, corporations, and local formal and customary elites.

Such mechanisms would demand, at a minimum: a) that investing corporations be more informed about local socio-cultural, economic and political dynamics on the ground, b) that funders and local governments support, report on and enforce more regular, culturally sensitive, and above all independent evaluations of project impacts, and c) that funders, government, corporations, and customary elites be held accountable for negative impacts by international and national civil society organizations. As noted above, these recommendations are broad and quite general. But they are aimed at overcoming cultural dissonance and the unpredictable negative impacts of the corporate application of resources in the many different contexts in which private industry is now active. It is only a concerted effort among supranational institutions, funding organizations, governments, and civil society that can hold such institutions accountable across this wide array of post-conflict contexts. 


\section{References}

Abdullah, Ibrahim. 1998. "Bush Path to Destruction: The Origin and Character of the Revolutionary United Front/Sierra Leone.” The Journal of Modern African Studies 36(2):203-235.

Baglioni, Elena and Peter Gibbon. 2013. "Land Grabbing, Large- and Small-Scale Farming: What can Evidence and Policy from $20^{\text {th }}$ Century Africa Contribute to the Debate.” Third World Quarterly 34(9):1558-1581.

Baka, Jennifer (2013) "The Political Construction of wasteland: Governmentality, Land Acquisition and Social Inequality in South India.” Development and Change 42(2):409428.

Bond, Jennifer. 2014. “A Holistic Approach to Natural Resource Conflict: The Case of Laikipia County, Kenya.” Journal of Rural Studies 34:117-127.

Bolton, Catherine. 2012. I Did it to Save My Life: Love and Survival in Sierra Leone. Berkeley, CA: University of California Press.

Borras Saturnino M. and Jennifer C. Franco. 2010. "From Threat to Opportunity? Problems with the Idea of a "Code of Conduct" for land grabbing." Yale Human Rights and Development Journal 13:507-523.

Boulding, Kenneth E. 1963. Towards a Pure Theory of Threat Systems. The American Economic Review 53(2): 424-434.

Buckley, Lila. 2013. “Chinese Land-Based Interventions in Senegal.” Development and Change 42(2):429-450.

Cotula, Lorenzo. 2013. “The New Enclosures? Polanyi, International Investment Law and the Global Land Rush.” Third World Quarterly 34(9):1605-1629.

De Schutter, Olivier. 2011. How Not to Think of Land-Grabbing: Three Critiques of LargeScale Investments in Farmland.” The Journal of Peasant Studies 38(2):249-279.

Doss, Cheryl, Gale Summerfield, and Dzodzi Tsikata. 2014. "Land, Gender, and food Security. Feminist Economics 20(1):1-23.

Dwyer, Michael B. 2013. "Building the Politics Machine: Tools for 'Resolving' the Global Land Grab.” Development and Change 42(2):309-333.

Edelman, Marc. (2013) Messy Hectares: Questions about the Epistemology of Land Grabbing Data.” The Journal of Peasant Studies 40(3):485-501. 
Fairbairn, Madeleine. 2013. "Indirect Dispossession: Domestic Power Imbalances and Foreign Access to Land in Mozambique.” Development and Change 42(2):335-356.

Fairhead, James, Melissa Leach, and Ian Scoones. 2012. “Green Grabbing: A New Appropriation of Nature?” The Journal of Peasant Studies 39(2):237-261.

Fanthorpe, Richard. 2001. “Neither Citizen nor Subject? 'Lumpen’ Agency and the Legacy of Native Administration in Sierra Leone.” African Affairs 100(400):363-386.

Franco, Jennifer, Leyla Mehta, and Gert Jan Veldwisch. 2013. “The Global Politics of Water Grabbing.” Third World Quarterly 34(9):1651-1675.

Geisler, Charles and Fouad Makki. 2014. "People, Power, and Land: New Enclosures on a Global Scale.” Rural Sociology 79(1):28-33.

Grandia, Liza. 2013. "Road Mapping: Megaprojects and Land Grabs in the Northern Guatemalan Lowlands.” Development and Change 42(2):233-259.

Gunnoe, Andrew. 2014. "The Political Economy of Institutional Landownership: Neorentier Society and the Financialization of Land.” Rural Sociology 79(4):478-504.

Hirsch, John L. 2001. Sierra Leone: Diamonds and the Struggle for Democracy. Boulder, CO: Lynne Rienner Publishers.

Holleman, Hannah. 2012. "Energy Policy and Environmental Possibilities: Biofuels and Key Protagonists of Ecological Change. Rural Sociology 77(2):280-307.

Ince, Onur Ulas. 2014. "Primitive Accumulation, New Enclosures, and Global Land Grabs: A Theoretical Intervention. Rural Sociology 79(1):104-131.

Keen, David. 2003. "Greedy Elites, Dwindling Resources, Alienated Youths: The Anatomy of Protracted Violence in Sierra Leone.” Internationale Politik und Gesellschaft 2:67-94

Kpundeh, Sahr. 2004. “Corruption and Political Insurgency in Sierra Leone.” Pp. 90-103 in Between democracy and terror: the civil war in Sierra Leone, edited by I. Abdullah. Dakar: Council for the Development of Social Science Research in Africa.

Makki, Fouad. 2014. "Development by Dispossession: Terra Nullius and the Sociol-ecology of New Enclosures in Ethiopia.” Rural Sociology 79(1):79-103.

Margulis, Matias E., Nora Mckeon, and Saturnino M. Borras Jr. 2013. "Land Grabbing and Global Governance: Critical Perspectives.” Globalizations 10(1):1-23.

McMichael, Philip. 2013. “Land Grabbing as Security Mercantilism in International Relations.” Globalizations 10(1):47-64. 2014. “Rethinking Land Grab Ontology.” Rural Sociology 79(1):34-55. 
Mehta, Lyla, Gert Jan Veldwisch, and Jennifer Franco. 2012. "Introduction to the Special Issue: Water Grabbing? Gocus on the (Re)appropriation of Finite Water Resources.” Water Alternatives 5(2):193-207.

Menzel, Anne. 2015. Foreign Investment, Large-Scale Land Deals, and Uncertain 'Development' in Sierra Leone: Impacts, Conflicts, and Security Concerns. CCS Working Paper No. 18. Retrieved August 29, 2016 (https://www.unimarburg.de/konfliktforschung/publikationen/wp18.pdf).

Millar, Gearoid. 2017. "For Whom do Local Peace Processes Function? Maintaining Control through Conflict Management.” Cooperation and Conflict 52(3): 293-308.

Millar, Gearoid. 2016a. "Knowledge and Control in the Contemporary Land Rush: Making Local Land Legible and Corporate Power Applicable in Rural Sierra Leone.” Journal of Agrarian Change 16(2):206-224.

Millar, Gearoid. 2016b. "Local Experiences of Liberal Peace: Marketization and Emerging Conflict Dynamics in Sierra Leone.” Journal of Peace Research 53(4):569-581.

Millar, Gearoid. 2015a. “'We have No Voice for That': Land Rights, Power, and Gender in Rural Sierra Leone.” Journal of Human Rights 14(4): 445-462.

Millar, Gearoid. 2015b. "Investing in Peace?: Foreign Direct Investment as Economic Justice in Sierra Leone.” Third World Quarterly 36(9):1700-1716.

Millar, Gearoid. 2015c. "Performative Memory and Re-victimization: Truth-Telling and Provocation in Sierra Leone.” Memory Studies 8(2):242-254.

Millar, Gearoid. 2014. An Ethnographic Approach to Peacebuilding: Understanding Local Experiences in Transitional States. London: Routledge.

Millar, Gearoid. 2012b. “'Ah Lef Ma Case fo God’: Religious Belief and Personal Autonomy in Sierra Leone’s Postwar Reconciliation.” Peace and Conflict: Journal of Peace Psychology 18(2):131-143.

Millar, Gearoid. 2011a. "Local Evaluations of Justice through Truth Telling in Sierra Leone: Postwar Needs and Transitional Justice.” Human Rights Review 12(4):515-535.

Millar, Gearoid. 2011b. "Between Western Theory and Local Practice: Cultural Impediments to Truth-Telling in Sierra Leone.” Conflict Resolution Quarterly 29(2):177-199.

Millar, Gearoid. 2010. "Local Evaluations of Truth Telling in Sierra Leone: Getting at 'Why' Though a Qualitative Case Study Analysis.” International Journal of Transitional Justice 4(4):477-496.

Mol, Arthur P.J. 2007. "Boundless Biofuels? Between Environmental Sustainability and Vulnerability. Sociologia Ruralis 47(4):297-315. 
Nnadozie, Emmanuel and Siham Abdulmelik. 2009. "The Role of the Private Sector in Sierra Leone's Post-Conflict Reconstruction Efforts.” Pp. 145-468 in From Civil Strife to Peace Building: Examining Private Sector Involvement in West African Reconstruction, edited by H. Besada. Waterloo: Wilfrid Laurier University Press.

Oliveira, Gustavo de L.T. 2013. Land Regularization in Brazil and the Global Land Grab.” Development and Change 42(2):261-283.

Ossome, Lyn. 2014. “Can the Law Secure Women’s Rights to Land in Africa? Revisiting Tensions between Culture and Land Commercialization.” Feminist Economics 20(1):15577.

Oya, Carlos. 2013. "Methodological Reflections on 'Land Grab’ Databases and the 'Land Grab’ Literature 'Rush'”’ The Journal of Peasant Studies 40(3):503-520.

Park, Augustine S.J. 2006. “Other Inhuman Acts: Forced Marriage, Girl Soldiers and the Special Court for Sierra Leone.” Social \& Legal Studies 15(3):315-337.

Peters, Krijn and Paul Richards. 1998. “'Why We Fight': Voices of Youth Combatants in Sierra Leone.” Africa 68(2):183-210.

Pham, J. Peter. 2007. "Making Sense of a Senseless War.” Human Rights and Human Welfare 7:35-51.

Plateau, Jean-Philippe. 1996. "The Evolutionary Theory of Land Rights as Applied to SubSaharan Africa: A Critical Assessment.” Development and Change 27(1): 29-86.

Ribot, Jesse C. 1999. Decentralisation, Participation and Accountability in Sahelian Forestry: A Legal Instrument of Political-Administrative Control. Africa 69(1): 23-65.

Ribot, Jesse C. and Nancy Lee Peluso. 2003. “A Theory of Access.” Rural Sociology 68(2):153-181.

Ribot, Jesse C., Ashwini Chhatre and Tomila Lankina. 2008. Introduction: Institutional Choice and Recognition in the Formation and Consolidation of Local Democracy. Conservation and Society 6(1): 1-11.

Sage, Colin. 2013. “The Interconnected Challenges for Food Security from a Food Regimes Perspective: Energy, Climate and Malconsumption.” Journal of Rural Studies 29:71-80.

Sassen, Saskia. 2013. "Land Grabs Today: Feeding the Disassembling of National Territory.” Globalizations 10(1):25-46.

Scoones, Ian, Ruth Hall, Saturnino M. Borras Jr., Ben White, and Wendy Wolford. 2013. "The politics of evidence: methodologies for understanding the global land rush." The Journal of Peasant Studies 10(3):469-483.

Shaw, Rosalind. 2010. "Linking Justice with Reintegration? Ex-combatants and the Sierra Leone Experiment.” Pp. 111-132 in Localizing transitional justice: interventions and 
priorities after mass violence, edited by R. Shaw, L. Waldorf and P. Hazan. Stanford, CA: Stanford University Press.

Shepler, Susan. 2005. "The Rites of the Child: Global Discourses of Youth and Reintegrating Child Soldiers in Sierra Leone.” Journal of Human Rights 4(2):197-211.

Tsikata, Dzodzi and Joseph Awetori Yaro. 2014. "When a Good Business Model is Not Enough: Land Transactions and Gendered Livelihood Prospects in Rural Ghana. Feminist Economics 20(1):202-226.

Tsing, Anna Lowenhaupt. 2005. Friction: An Ethnography of Global Connection. Princeton, NJ: Princeton University Press.

Uphoff, Norman. 1989. "Distinguishing Power, Authority \& Legitimacy: Taking Max Weber at his World by Using Resources-Exchange Analysis. Polity 22(2): 295-322.

Verma, Ritu. 2014. "Land Grabs, Power, and Gender in East and Southern Africa: So, What's New?” Feminist Economics 20(1):52-75.

White, Jennifer and Ben White. 2012. "Gendered Experiences of Dispossession: Oil Palm Expansion in a Dayak Hibun Community in West Kalimantan.” The Journal of Peasant Studies 39(3-4):995-1016.

White, Ben, Saturnino M. Borras Jr., Ruth Hall, Ian Scoones, and Wendy Wolfrod. 2012. "The New Enclosures: Critical Perspectives on Corporate Land Deals." The Journal of Peasant Studies 39(3-4):619-647.

Wolford, Wendy, Saturnino M. Borras Jr., Ruth Hall, Ian Scoones, and Ben White. 2013. Governing Global Land Deals: The Role of the State in the Rush for Land.” Development and Change 44(2):189-210.

Woodhouse, Philip and Ana S. Ganho. 2011. "Is Water the Hidden Agenda of Agricultural Land Acquisition in Sub-Saharan Africa?” International Conference on Global Land Grabbing Paper, April 6-8. Sussex, England. Retrieved August 30, 2016 (http://www.iss.nl/fileadmin/ASSETS/iss/Documents/Conference_papers/LDPI/12_P_W oodhouse_and_A_S_Ganho.pdf). 